\title{
Formation of personality psychological maturity and adulthood crises
}

\author{
Victoria R. Manukyan, Larisa A. Golovey ${ }^{\star}$, Olga Yu. Strizhitskaya \\ Saint Petersburg State University, Saint Petersburg, Russia \\ ${ }^{*}$ Corresponding author. E-mail: lgolovey@yandex.ru
}

Based on theoretical analysis, in the present paper, we defined the structure of the characteristics of personality psychological maturity, which is considered an adult development criterion. The objective of this paper was to identify the mechanisms that contribute to the formation of psychological maturity in adulthood development. We first assumed that one of the possible mechanisms is the normative crisis of development. In turn, previously formed psychological maturity traits can relieve the experiences associated with this normative crisis. The aim of the present study was to analyze the formation of psychological maturity during periods of emerging and middle adulthood, with a specific focus on normative crisis experiences. The study design included cross-sectional and longitudinal methods. The participants included 309 adults. The emerging adulthood group ranged in age from 18 to 25 years, and the participants in the middle adulthood group were between 38 and 45 years of age. To study crisis events and experiences, we used three author-designed questionnaires. A self-actualization test by E. Shostrom (SAT), the Big Five personality test by Costa and MacCrae, a value and availability ratio in various vital spheres technique by E.B. Fantalova, a purpose-in-life test by D.A. Leontiev, and a coping test by Lazarus were used to define the personality characteristics used to overcome difficult life situations.

In this paper, we described experiences specific to the crises associated with emerging adulthood and middle adulthood in the context of developmental tasks. Using cluster analysis, we defined groups with different intensities of crisis experiences and analyzed psychological content of crisis experiences in different groups. Using ANOVA, we found that participants with low intensity crisis experiences show more developed characteristics of psychological maturity. During emerging adulthood, the overcoming of crises associated with the separation from family contributes to the formation of such aspects of psychological maturity as self-management, life organization and responsibility. In a longitudinal study of midlife crises, the data suggest that in groups where there are more intense crisis experiences, there are more significant dynamics in the meaning and value sphere over the course of a year that lead to the achievement of greater personal integrity and congruence.

The current study proved the hypothesis regarding the role of the crisis mechanism of psychological maturity development in two phases of adulthood. It also proved that psychological maturity contributes to a decrease in the intensity of crisis experiences.

Keywords: development, adulthood, psychological maturity, crisis, crisis experiences, meaning and value sphere 


\section{Introduction}

Adulthood is the largest developmental period of a human lifespan. It includes the transition to a profession, the development of social and professional roles, the building of an active professional life, the formation of a family and the raising of children. Additionally, this period is associated with mentoring, wisdom, intergenerational relationships and the dismissal from or ending of one's professional life. An understanding of the developmental principals, factors and characteristics involved in personality formation during different periods of adulthood is crucial for the development of social and psychological career development programs, family support programs, and psychological counseling and for the understanding of the mechanisms of human development. In our study, we assumed that psychological maturity could be one of the phenomena that indicate adult personality development (Golovey, 2012a). There are current studies that have attempted to identify the psychological content associated with the notion of adult personality development (Sukhobskaja (2002), Sergienko (2007), Nartova-Bochaver (2007), Kharlamenkova (2007)). In approaching this concept, the authors discuss the main characteristics of psychological maturity, noting the complexity and ambiguity of the definition of maturity in general and personality maturity in particular (Portnova, 2008; Shlyapnikova, 2010). Researchers have attempted to define the content of this concept in the context of personality potential such that personality potential is considered a characteristic of personality maturity (Leontiev, 2011). Some researchers have assumed that the main criterion of psychological maturity is personality self-determination, i.e., the ability to act in relative freedom of the given conditions (both external and internal) or in spite of the conditions (Abulkhanova-Slavskaya, 1999; Leontiev, 2011; Sergienko, 2007). Consistent with other researchers, we consider the psychological maturity of personality to be a complex phenomenon consisting of several criteria.

By analyzing existing approaches, we found a lack of clarity with respect to the definitions of psychological maturity and its criteria. Thus, we aimed to determine the most universal and significant characteristics to operationalize this phenomenon. From a generalized perspective, psychological maturity could be considered as the integration of two aspects: individual psychological (intrapersonal) and social psychological (interpersonal). Based on theoretical analysis, most recognized criteria of the psychological maturity of personality are represented below (Dermanova, Manukyan, 2012):

1. Responsibility (E. Fromm, E. Ericson, A.A. Rean, A.G. Asmolov, C. Rogers, S.K. Nartova-Bochaver).

2. Reflexiveness, awareness (G. Allport, A. Maslow, C. Rogers, N.E. Kharlamenkova, K.A. Abulkhanova-Slavskaya, R.M. Shamionov, G.S. Sukhobskaya).

3. Self-development (A. Maslow, C. Rogers, A.A. Rean, K.A. Abulkhanova-Slavskaya, A.L. Zhuravlev).

4. Self-acceptance and self-respect (G. Allport, C. Rogers, N.E. Kharlamenkova, R. Kassel).

5. Autonomy (C. Rogers, F. Perls, L.I. Bozhovich, J. Loevinger, S.K. NartovaBochaver, D.A. Leontiev).

6. Viability (B.G. Ananiev, C. Rogers, G. Allport, D.A. Leontiev). 
7. Self-management and life organization (B.G. Ananiev, E.F. Rybalko, G.S. Sukhobskaya, A.G. Asmolov, K.A. Abulkhanova-Slavskaya, R.M. Shamionov).

8. Integrity and congruence (C. Rogers, B.G. Ananiev, N.E. Kharlamenkova, J. Loevinger, C.G. Jung, E. Ericson).

9. Width of social network (G. Allport, B.G. Ananiev, D.A. Leontiev).

10. Tolerance, moral consciousness, humanistic values (G. Allport, A.A. Rean, G.S. Sukhobskaya, L. Kohlberg, A.A. Derkach, A.A. Bodalev, A.G. Asmolov, N.E. Kharlamenkova, A.L. Zhuravlev, R.M. Shamionov).

11. Positive social relations (H. Sullivan, G. Allport, Z. Freud, E. Fromm, E. Ericson, C. Rogers).

In the given classification, the first nine criteria characterize intrapersonal aspects of maturity, while the last two (10 and 11) constitute the interpersonal characteristics of psychological maturity.

It is noted that despite a wide discussion on the phenomenon of psychological maturity, the number of empirical studies that reveal factors, conditions and mechanisms of the formation of psychological maturity is insufficient. Few extant studies consider the formation of personality maturity during different periods of adulthood.

Therefore, it is extremely important to determine what mechanisms contribute to the personal growth, integrity and personal development of an adult whose personality remains psychologically underdeveloped. During adulthood, the role of development of such mechanisms as isolation and compensation increases as they provide self-development and self-actualization of personality. However, the process of personal development is quite dramatic, largely due to the impact of life crises, which are often the result of a psychological trauma. Comparing data on normative crises in adulthood with identified criteria of psychological maturity, we find specific characteristics associated with different crises that occur during adulthood. For example, the transition to adulthood begins with the crisis of emerging adulthood (Khukhlaeva 2002, Sheehy, 1999; Slobodchikov, Isayev, 2000; Krasilo, 2007; Arnett, 1997; Tanner, Arnett, 2009).

The essence of this crisis is associated with the transition to a new value-semantic community of adults that involves separation, individuation, self-actualization, awareness and acceptance of responsibility - these are the parameters that distinguish an adult from a child and an adolescent. Crises emerging during training in high school and the first stages of professional work (professional expectations crisis), in our opinion, should be considered as part of an overall adaptation process of emerging adulthood. The psychological formations of overcoming the crisis of emerging adulthood are defined by parameters of personality maturity such as autonomy, self-management, life organization and the ability to form close relationships.

In middle adulthood, there appear different types of crises, referred to as midlife crises, as they generally occur when the individual is in his/her 30s and 40s (Levinson, 1986; Sheehy, 1999; Hermans, Oles, 1999; Morgun, Tkachev, 1981; Slobodchikov, Isayev, 2000; Soldatova, 2007). According to most authors, the crisis of the 30th birthday marks the transition from youth to middle adulthood. Termed flourishing, this is when certain formations or characteristics in the personality 
structure tend to appear. Such formations include self-acceptance of the present, an awareness of the value of being yourself, values and conscious choices regarding the direction of self-development (Soldatova, 2007). With respect to the criteria of personality maturity, psychological formations during the midlife crisis for those in their 30s are associated with a more complete acceptance of self, accompanied by a focus on self-development. The most important characteristics acquired during crises that occur for those in their 40s are congruence, integrity, increasing autonomy, consciousness and reflectivity (Hollis, 2008; Sheehy, 1999; Soldatova, 2007). A number of studies claim that responsibility is one of the major acquisitions during the middle adulthood crisis (Erikson, 1996; Muzdybaev, 1980). Some researchers (Jung, 1996; Slobodchikov, Isayev, 2000; Lukin, 2006) also note an increase in the awareness of belonging to the world, an awareness that can be manifested through such characteristics of personal maturity as tolerance, moral consciousness, humanistic values and diverse relations with the world.

\section{Study design}

Based on an analysis of specific tasks at different periods of adult development and the corresponding characteristics of the crises, hypotheses and aims of the empirical study were formulated.

Hypotheses: 1. Because the crisis mechanism is associated with the formation of new characteristics of personality, developmental crises can serve as the mechanisms for psychological maturity formation and adult personality development. 2 . Previously formed qualities of psychological maturity may decrease the crisis experience and enable the individual to better cope with normative crises.

Aims: 1. To analyze the crises associated with various stages of adulthood as possible mechanisms that contribute to the development of the psychological maturity of adults. 2. To justify and empirically study the indicators of personality maturity in different periods of adulthood.

To approach these aims, we conducted two cycles of studies. The first cycle dealt with the study of adulthood crises in association with the characteristics of psychological maturity. The second cycle aimed to study the criteria and indicators of personality psychological maturity development during different periods of adulthood.

\section{Empirical study on early adulthood crises and personality psychological maturity}

\section{Method}

The sample for this study, which examined the psychological content of early adulthood crises with regard to the parameters of psychological maturity, included 266 students with varied profiles regarding training and education. To study the nature and severity of the crisis experiences, we used specially designed questionnaires a questionnaire for the analysis of occupational choice and training and a questionnaire about crisis events and experiences, which was designed for students by V.R. Manukyan (Vasilenko, Manukyan, 2006). 
The questionnaire for analysis of occupational choice and training consisted of 15 questions with several options and focused on information regarding factors of occupational choice, validity of occupational choice, existence of occupational plan, satisfaction with occupational choice, dynamics of attitudes toward profession during training, self-confidence regarding abilities during training. The questionnaire that addressed crisis events and experiences (for students) consisted of 24 statements that described particular experiences considered to be typical phenomenological characteristics of adulthood crises in general and emerging adulthood in particular. The characteristics included biographical crisis experiences, phenomenology of internal conflict and difficulties with self-determination, separation from family, onset of professional training and participation in professional activities (table 1 presents 15 of the 24 statements). The participants ranked the statements on a 10 point scale that ranged from 1 - minimal intensity of an experience to $10-$ strong experience and where ( 0 denoted the absence of experience. For interpretation, statements are considered as a whole in correspondence with each other. In this way, the analysis allows for a more precise description of the phenomenological structure of the crisis, the definition of the crisis and the major and minor experiences.

To determine the personality factors and features that help to overcome difficult situations, we used the self-actualization test by E. Shostrom (SAT), the Big Five personality test by Costa and MacCrae and the coping test by R. Lazarus.

Table 1. Significant differences in terms of student crisis experiences between cluster groups

\begin{tabular}{|c|c|c|c|c|}
\hline Events, experiences & $\begin{array}{c}\mathbf{M} \\
\text { (pros) }\end{array}$ & $\underset{\text { (cris) }}{\mathrm{M}}$ & $\mathbf{F}$ & $\mathbf{p}$ \\
\hline $\begin{array}{l}\text { 1. Depreciation of past successes and their irrelevance at } \\
\text { present time }\end{array}$ & 2,31 & 5,11 & 67,35 & 0,00 \\
\hline 2. Lack of significantly attractive future goals & 2,46 & 6,23 & 111,26 & 0,00 \\
\hline 3. Feelings of strong fatigue, lack of energy regarding activities & 4,01 & 6,76 & 55,28 & 0,00 \\
\hline 4. Ambiguity, unpredictability of the future & 4,11 & 7,40 & 117,28 & 0,00 \\
\hline 5. Difficulties in orientation in a complex flow of events & 2,81 & 5,50 & 77,87 & 0,00 \\
\hline 6. Difficulties in defining future development directions & 3,47 & 6,77 & 107,37 & 0,00 \\
\hline 7. Regrets about lost chances & 4,65 & 7,22 & 48,68 & 0,00 \\
\hline 8. Experiencing lack of meaning in life & 2,85 & 6,06 & 76,69 & 0,00 \\
\hline 9. Conflict between two equally important needs, goals & 4,06 & 6,20 & 28,59 & 0,00 \\
\hline $\begin{array}{l}\text { 10. Questions regarding self-image (“who I am?", "whom would } \\
\text { I like to be?" etc.) }\end{array}$ & 3,83 & 6,63 & 59,20 & 0,00 \\
\hline $\begin{array}{l}\text { 11. Difficulties in distribution of time and power between differ- } \\
\text { ent spheres of life (training, communication, vocation etc.) }\end{array}$ & 5,17 & 6,93 & 25,158 & 0,00 \\
\hline $\begin{array}{l}\text { 12. Difficulties regarding the beginning of professional training } \\
\text { (making conspectus and understanding lectures, independ- } \\
\text { ent work with sources) }\end{array}$ & 2,37 & 5,14 & 81,84 & 0,00 \\
\hline 13. Feelings of loneliness & 3,17 & 6,40 & 82,75 & 0,00 \\
\hline 14. Experiences of yearning for schoolmates, friends & 1,96 & 3,82 & 32,11 & 0,00 \\
\hline 15. Difficulties in communication with college mates & 1,46 & 3,77 & 66,43 & 0,00 \\
\hline
\end{tabular}


The study design was based on the principle of the allocation of the total sample of two groups, tentatively called "prosperous" $(\mathrm{N}=155)$ and "crisis" $(\mathrm{N}=111)$ (based on cluster analysis), and their comparison. The crisis group was characterized by a significantly higher level of crisis experiences (Table 1).

\section{Results}

The main experiences in both groups involve difficulties with time and energy management during different spheres of their lives (education, communication, recreation, work, etc.) as well as feelings of extreme fatigue. Such experiences reflect the difficulties and complexities associated with self-organization experienced by all students. For all students, biographical experiences, i.e., uncertainty and unpredictability of the future and regret about missed opportunities, are relevant, although to different degrees, and thus reflect the current process of an awareness of life during this stage. In the group with crisis experiences, these difficulties are combined with intense emotions regarding self-image, feelings of loneliness and difficulties determining the direction of their own development, thus indicating the relevance of their past experiences, as these experiences contributed to their development during their youth - a period of active personal and professional self-determination. In the relatively prosperous group, the structure of crisis experiences reveals the fullness of students' lives and their desire for self-realization.

Table 2. Significant differences in terms of personality characteristics between cluster groups

\begin{tabular}{lcccc}
\hline \multicolumn{1}{c}{ Characteristic } & M (prosp) & M (cris) & F & p \\
\hline Emotional stability ( Big Five, IV) & 47,64 & 53,16 & 19,64 & 0,000 \\
Time competence (SAT) & 52,59 & 41,58 & 23,66 & 0,000 \\
Support (SAT) & 55,39 & 51,32 & 11,36 & 0,001 \\
Value orientation (SAT) & 56,92 & 51,46 & 8,202 & 0,005 \\
Flexibility (SAT) & 56,70 & 52,3 & 5,097 & 0,025 \\
Sensitivity (SAT) & 57,27 & 52,4 & 5,500 & 0,02 \\
Spontaneity (SAT) & 56,94 & 52,26 & 5,889 & 0,016 \\
Self-respect (SAT) & 62,64 & 51,00 & 28,874 & 0,000 \\
Self-acceptance (SAT) & 18,52 & 13,23 & 4,868 & 0,028 \\
Acceptance of aggression (SAT) & 56,56 & 52,63 & 3,99 & 0,047 \\
\hline
\end{tabular}

A comparative study between these two groups of personality characteristics (Table 2) enables us to characterize the prosperous group of students as significantly more emotionally stable, self-confident, calm, realistic and adaptable and thus better able to cope with difficulties (factor 4, emotional stability, of the Big Five). The values for this factor are in the range of medium for the prosperous group and high for the crisis group. The results indicate that those in the crisis group are emotionally unstable, impulsive, moody and unable to cope with reality. A correla- 
tion of the psychological content associated with the emotional stability factor with our criteria of maturity suggests that this characteristic is one of the conditions for developing viability as an aspect of maturity.

Distinctions regarding the scales of the SAT reveal areas of internal resources among students from the prosperous group that are a result of their greater psychological maturity. Among the groups of students, significant distinctions are revealed on the nine scales of the self-actualization test $(0.000 \leq p \leq 0.047)$, where parameters of psychological maturity, such as self-government and life organization (the "competence of time" scale); autonomy (the "support" scale); self-acceptance, self-esteem, awareness and reflectivity (the "sensitivity", "spontaneity", "acceptance of aggression" scales); and tolerance and humanistic values (the "valuable orientations" and "flexibility" scales), are revealed. Broad coverage of the revealed distinctions further indicate that the students from the prosperous group demonstrate more expressed characteristics of psychological maturity than do students from the crisis group. With respect to the students with expressed crisis experiences, lower indicators of psychological maturity and also the existence of the problems connected with the unsuccessful efforts to overcome the crisis from the previous period of development are characteristic.

Considering that one of the problems during the period of early adulthood is separation from a parental family, we studied the distinctions between the students living in a parental family (180 people) and those living separately from their parents (106 people). An ANOVA analysis was used (Table 3).

Table 3. Significant differences in terms of crisis experiences and personality characteristics among in-city and out-of-city students

\begin{tabular}{lcccc}
\hline \multicolumn{1}{c}{ Characteristic } & $\begin{array}{c}\text { M } \\
\text { (SPb) }\end{array}$ & $\begin{array}{c}\text { M (out-of- } \\
\text { city) }\end{array}$ & F & p \\
\hline $\begin{array}{l}\text { Depreciation of past successes and their irrelevance } \\
\text { at present time }\end{array}$ & 3,13 & 4,10 & 6,29 & 0,013 \\
$\begin{array}{l}\text { Experiencing a lack of meaning in life } \\
\text { Experiencing loneliness }\end{array}$ & 3,84 & 4,78 & 4,88 & 0,028 \\
Difficulties communicating with college mates & 4,12 & 5,16 & 6,34 & 0,012 \\
Painful separation from family, support of close & 2,18 & 2,85 & 4,27 & 0,04 \\
people and transition to self-support & 1,68 & 4,05 & 45,39 & 0,000 \\
Separation from childhood friends & & & & \\
Confidence about future & 2,62 & 3,60 & 6,77 & 0,01 \\
Living with parents or separately & 10,17 & 11,07 & 7,98 & 0,005 \\
Self-control (Big Five) & 3,79 & 2,17 & 223,3 & 0,000 \\
Emotional stability (Big Five) & 50,74 & 55,49 & 23,01 & 0,000 \\
Self-control (Lazarus, \%) & 48,46 & 51,00 & 3,99 & 0,047 \\
Distancing (Lazarus, \%) & 55,46 & 60,49 & 8,01 & 0,005 \\
Accepting responsibility (Lazarus, \%) & 45,84 & 50,57 & 4,34 & 0,038 \\
Planned problem-solving (Lazarus, \%) & 59,33 & 64,41 & 4,36 & 0,038 \\
\hline & 64,86 & 69,65 & 4,81 & 0,029 \\
\hline
\end{tabular}


The results reflect specific aspects of the crises experienced by students living separately. Such aspects include a significantly greater expression of difficulties associated with the social and psychological adaptation to the painful separation from family, the loss of support of close people and the transition to self-support; difficulties communicating with classmates; difficulties adjusting to the separation from childhood friends; and feelings of loneliness $(0.000 \leq \mathrm{p} \leq 0.04)$.

Furthermore, students living separately are more inclined to depreciate their latest progress because in the new environment, it is irrelevant as they must now develop new abilities, make new friends, and rebuild their image anew. Accordingly, these students endure a sharper transition into emerging adulthood, which is also supported by significantly more intense experiences of an existential vacuum. For such students, entering higher education institutions is the central phase of the separation from parental families, which is reflected in the nature of their experiences, in their personal characteristics and in their coping behaviors.

ANOVA results reveal that students living separately from their parental families are more inclined to take responsibility and that they exhibit significantly more coping strategies, better self-control and better problem-solving skills. The expression of significant coping strategies reflects the great intensity of the course of their crises. The maximum divergence between the groups, based on the values $\mathrm{F}=23.01$ and $\mathrm{p}=0.000$, is specific to the strategy of self-control, which is characterized by significantly higher levels in combination with self-control over behavior as a personal quality, according to the Big Five. At the same time, the emotional stability of the students living separately from their parental families is low, i.e., they attempt "to seize their emotionality" in an attempt to suppress or control it. As the quantity of difficulties endured is possibly too great, they may be compelled to separate or distance themselves from some of the problems. The results reveal that students who are living separate from their families develop the ability to selfcheck their behaviors, are inclined to accept responsibility and search for reasons or causes for their failures. On this basis, we conclude that overcoming the crisis of separation from a parental family likely promotes the formation of certain aspects of personality psychological maturity, such as self-government and life organization skills as well as a sense of responsibility.

\section{Empirical study on middle adulthood crises and personality psychological maturity}

\section{Method}

In the studies conducted previously, we obtained data, with respect to the valuable and semantic sphere, on midlife transformations occurring in the valuable and semantic sphere such as the development of greater tolerance and humanistic values. It has been found that during the period of middle adulthood, personal characteristics that correspond to the parameters of personality psychological maturity have a regulating impact on the experiences associated with the aging crises. These characteristics include responsibility, self-acceptance, life organization skills and social relationships (Manukyan, 2009). As individuals approach their 40s, per- 
sonality changes such as increased awareness and reflectivity on their own life have been revealed (Golovey, Manukyan, 2003).

Proceeding from these data, we concentrated the research on the analysis of the dynamics of the valuable and semantic in connection with the experiences of midlife crises. A total of 43 people (13 men and 30 women) between the ages of 38 and 45 years participated in the research, though only 23 (14 women and 9 men) participated in the longitudinal study. The following techniques were used: a questionnaire on age-related changes, life orientations technique by D.A. Leontiev, a crisis experience questionnaire by V. R. Manukyan (Vasilenko, Manukyan, 2006), a technique to establish value and availability ratios for various vital spheres by E.B. Fantalova (Fantalova, 2001), a survey on the definition of the psychological content of perceivable age changes. The survey asked, "What changes are happening (or happened) to you with regards to your 40th birthday, and with what are the changes associated? Please describe what you have noted," Participants were offered 18 spheres in which they could reply to this question. In each sphere, they were to write their description in free form. Spheres with no changes were kept. The survey was analyzed using content analysis.

\section{Results}

The analysis of the entire selection revealed that from the 18 spheres, adults marked changes in an average of 10 spheres. The nature of the realized changes was depicted using content analysis, the results of which showed that the majority of respondents experienced health deterioration (61.29\%), realized the transience of time (50\%), and noted changes in appearance $(53.13 \%)$. At the same time, there was an internal process of reconsideration, taking responsibility, summing up time lived, reorganizing the present and creating the future $(44.44 \%)$. During this period, an interest in spheres such as nature (68\%), art (56\%) and religion (44.44\%) increased. Moreover, there was an increase in understanding and tolerance with respect to the attitudes of other adults (46.43\%) and children (37\%). The data further reflect personal changes that include increased responsibility, greater tolerance in personal relations and an increase in social communications that extend beyond the limits of self and toward transcendence.

The correlation analysis of the interrelations among the indicators of the crisis, as well as the valuable and semantic sphere, revealed that experiences associated with midlife crises were accompanied by a disintegration in the motivation and personal spheres of adults following both conflict and vacuum type experiences $(\mathrm{p} \leq 0.01)$. When experiencing a midlife crisis, the most difficult spheres to recognize or adapt to are active life, love, freedom in behavior and actions and self-confidence.

A cluster analysis of the characteristics of crisis expressiveness revealed three groups that significantly differed on a number of indicators $(0.000 \leq p \leq 0.05)$. Representatives of the crisis group (34.8\%) were characterized by high values for overall crisis expressiveness, higher overall anxiety and a greater number of changes related to their 40th birthday. Compared with other groups, the crisis group also expressed the lowest scores for satisfaction with life and feelings of happiness. In this group, the highest levels of disintegration in the motivational and personal spheres were 
also revealed. Participants in the middle group (47.8\%) were characterized by average values for the majority of indicators. The safe group (17.4\%) was found to have low scores for overall crisis expressiveness, general anxiety, and noted changes. Additionally, this group was characterized by a high level of satisfaction with life and a low level of disintegration in the motivational and personal spheres.

An analysis of the dynamics of the valuable and semantic sphere (assessed using the Wilcoxon test) suggests, for adults in the same crisis phase, changes occur within one year regarding the values of love and self-confidence (Table 4).

Table 4. Significant shifts in investigated characteristics (Wilcoxon criteria): results from a longitudinal study

\begin{tabular}{|c|c|c|c|c|c|c|}
\hline Characteristic & $\begin{array}{c}\text { M } \\
\text { Time } 1\end{array}$ & $\begin{array}{c}\text { Mean } \\
\text { Time } 2\end{array}$ & $\begin{array}{c}\text { Number } \\
\text { “+ “ rankings }\end{array}$ & $\begin{array}{c}\text { Number } \\
\text { “_” rankings }\end{array}$ & $\mathrm{Z}$ & Sign. \\
\hline \multicolumn{7}{|c|}{ Significant shifts for group 1 with pronounced crisis experiences } \\
\hline C5 (love) & 9,25 & 7,38 & 1 & 6 & $-2,156$ & 0,031 \\
\hline C8 (self-confidence) & 6,5 & 4,88 & 0 & 6 & $-2,232$ & 0,026 \\
\hline \multicolumn{7}{|c|}{ Significant shifts for group 2 with intermediate crisis experiences } \\
\hline Number of changes & 8,55 & 10,91 & 7 & 2 & $-2,257$ & 0,024 \\
\hline Locus of control - life & 29,27 & 32,73 & 9 & 2 & $-2,097$ & 0,036 \\
\hline C5 (love) & 8,73 & 8 & 1 & 7 & $-2,126$ & 0,033 \\
\hline \multicolumn{7}{|c|}{ Significant shifts for group 3, "safe", without crisis experiences } \\
\hline $\begin{array}{l}\text { C7 (having real true } \\
\text { friends) }\end{array}$ & 4 & 6 & 4 & 0 & $-2,000$ & 0,046 \\
\hline
\end{tabular}

As noted previously, these values are the most difficult to realize, and the breakdown in these spheres closely correlates with experiences related to midlife crises. We further note that the changes in the group with pronounced crisis experiences are connected to the decrease in the importance of the specified values. That is, they are directed toward the smoothing of the internal conflict and an increase in integrity and congruence of the personality.

The shifts generally related to the valuable and semantic sphere were also found in adults with low levels of crisis experience expressiveness (intermediate group). Adults in this group also reinterpret the value of love in the direction of decreased importance. Representatives of this group began, within a year, to pay more attention to the changes they were experiencing, as indicated by the number of changes in connection with the 40th birthday, and at the same time, they began to believe they had the ability to manage their own life, as indicated by the locus of control - life, life-meaning orientations. In the third group of participants, where crises were not as prevalent, the shifts were minimal, which is characteristic of a stable period of development. However, a re-evaluation of the availability of good and loyal friends towards an increase in the importance of friends was observed in this group. 
In general, this research indicates that shifts in valuable orientations are more characteristic for adults who enduring normative crises, and it empirically confirms the assumptions of the impact of the crisis mechanism of development on an adult's identity. In the crisis groups, changes aimed to reduce the significance of values in the fields most difficult to implement and in those most associated with the experiences of midlife crises. The changes aimed to reduce the gap between the desired and the available and to restore the integrity of the person, which generally reflects the positive nature of the changes.

\section{Discussion}

This study revealed a close relationship between the indicators of the psychological maturity of a personality and the character and timing of experiences related to age-specific crises. The crisis experiences are determined by developmental tasks and developmental situations, and thus, the crisis experiences of early adulthood differ from those of middle adulthood. Characteristics of life tasks solved by adults in early and middle adulthood as revealed in our study are consistent with other research (Khukhlaeva, 2002; Sheehy, 1999; Slobodchikov, Isaev, 2000; Krasilo 2007, Levinson, 1986; Morgun, Tkacheva, 1981; 2000; Soldatova, 2007).

A study of crisis symptoms found individual differences in the intensity of the experiences such that low-intensity crisis experiences are associated with more pronounced characteristics of psychological maturity. Thus, we assume that these lowintensity experiences are factors in preventing crisis development. This is evidenced both in the structure of students' experiences connected with life completeness and aspirations toward self-realization and in the overt expression of qualities associated with more mature personalities, particularly such qualities as self-government, life organization skills, autonomy, self-acceptance, self-esteem, sensibility, reflectivity, tolerance, humanistic values and resilience. As these parameters of personality psychological maturity started forming earlier, students can exploit these qualities as they have become internal resources. That being said, the development of these parameters is not yet completed.

Regardless of the degree of development of personal maturity, all young people have difficulty with self-organization, and they endure difficulties with time distribution and with conflicts between and among various spheres of life. Overcoming these difficulties leads to the development of various aspects of psychological maturity such as self-management and life organization. Young adulthood is the first time students are confronted with such problems and solutions, and thus, this parameter is specific to the period of early adulthood. The development of the self-management and life-organization parameter is most intense among those young people who are coping with the separation from their parental families and living separately from their parents. Thus, their crisis experiences are more pronounced.

Our studies on middle age maturity show that an impending 40th birthday is associated with such characteristics of psychological maturity as tolerance, moral consciousness and humanistic values. There is an increase in sensibility and reflectivity concerning one's life that is discerned by the individual him/herself. The respondents' marked personality changes reflect the ongoing transformation in 
the direction of increased expressiveness of responsibility and in the expanding of relations with the world beyond the limits of self (art, religion, nature) and toward transcendence. Most dynamics were observed in groups with the highest crisis experiences in the value-semantic field, which empirically confirms the assumptions regarding the effect of the crisis mechanisms of development on the adult's identity.

\section{Conclusion}

Personality maturity is an ongoing developmental process that occurs throughout the stages studied herein. Moreover, we can assume that psychological maturity is formed only after transitioning through the crisis of middle age, a conclusion that is consistent with the concepts regarding development in adulthood (Ericson, 1996; Jung, 1996; Slobodchikov, Isaev, 2000; Lukina, 2006) and is also consistent with our previous research (Golovey, Manukyan, 2003; Golovey, 2012).

The results of this study suggest that during various stages of maturity, depending on specific problems of development, there is a primary formation of certain parameters of psychological maturity, while the already created parameters act as resources for overcoming difficult situations during the subsequent stage of development, which in turn results in successfully surmounting these new situations. The failure to overcome a crisis from the previous stage impedes the formation of mature personality traits, thus supporting the hypothesis about the relationship between crisis mechanisms and psychological maturity development. The results further reveal a continuity of crisis experiences during different periods of adulthood and indicate that difficult life situations, difficult tasks suggested by life and the process of overcoming these challenges contribute to the formation of psychological maturity and the successful resolution of normative developmental crises in adulthood.

\section{Acknowledgments}

The authors acknowledge Saint-Petersburg State University for Research Grant № 8.0.177.2010 (Investigators: Golovey L.A., Loginova N.A., Dermanova I.B., Manukyan V.R., Anisimova O.M., Petrash M.D., Galimsyanova M.V., Troshikhina E.G., Danilova M.V., Strizhitskaya O.Yu.).

\section{References}

Abulkhanova-Slavskaja, K. A. (1999). Psikhologija i soznanie lichnosti [Psychology and personality consiousness]. Moscow, Voronezh: Modek.

Arnett, J. J. (1997). Young People's Conceptions of the Transition to Adulthood. Youth Society, 29(1), 3-23. doi: 10.1177/0044118X97029001001

Dermanova, I. B., \& Manukyan, V. R. (2010). Lichnostnaja zrelost': k opredeleniju psikhologicheskogo soderzhanija [Personality maturity: to description of psychological phenomenon]. Vestnik Sankt-Peterburgskogo universiteta [Saint Petersburg University Bulletin], 4(12), 68-73.

Erikson, E. (1996). Detstvo i obshhestvo [Childhood and society]. Saint Petersburg: Lenato i dr. (Original work published 1950) 
Fantalova, E.B. (2001). Diagnostika i psikhoterapija vnutrennego konflikta [Diagnostics and psychotherapy on internal conflict]. Samara: Bahrah-M.

Golovey, L. A. (2012). Psikhologicheskaja zrelost' lichnosti v raznye periody vzroslosti [Psychological maturity of a personality at different stages of adulthood]. Psikhologija zrelosti $i$ starenija [Psychology of Maturity and Senility], 3(59), 5-18.

Golovey, L. A., \& Manukyan, V. R. (2003). Psikhobiograficheskoe izuchenie krizisov vzroslogo perioda razvitija [Psychobiographical research of crises of adult period of development]. Vestnik Sankt-Peterburgskogo universiteta [Saint Petersburg University Bulletin], 4(6), $100-112$.

Hermans, H. J., \& Oles, P. K. (1999). Midlife Crisis in Men: Affective Organization of Personal Meanings. Human Relations, 52(11), 1403-1426. doi: 10.1177/001872679905201103

Jung, C. G. (1996). Problemy dushi nashego vremeni [The spiritual problem of modern man]. Moscow: Univers. (Original work published 1928)

Kharlamenkova, N. E. (2007). Spontannost i kontrol v zrelykh lichnostnykh otnoshenijakh [Spontaneity and control in mature personality relationships]. In A.L. Zhuravlev \& E.A. Sergienko (Eds.), Fenomen i kategorija zrelosti v psikhologii [Phenomenon and category of maturity in psychology]. (pp. 128-148). Moscow: Institute of Psychology of RAS.

Khollis, D. (2008). Pereval v seredine puti: Kak preodolet krizis srednego vozrasta i najjti novyjj smysl zhizni [Pass at the middle of the way: how to overcome middle age crisis and to find new meaning in life]. Moscow: Kogito-Centr.

Khukhlaeva, O. V. (2002). Psikhologija razvitija: molodost, zrelost, starost [Developmental psychology: youth, maturity, aging]. Moscow: Akademia.

Krasilo, D. A. (2006). Orientirujushhijj obraz nastavnika v period vkhozhdenija vo vzroslost' [Orienting image of a tutor in the period of emerging adulthood]. Psikhologicheskaja nauka i obrazovanie [Psychological Science and Education], 1, 50-62.

Leontiev, D. A. (2011). Lichnostnyjj potencial, kak potencial samoreguljacii [Personality potential as a potential of self-regulation]. In D.A. Leontiev (Ed.), Lichnostnyjj potencial: struktura i diagnostika [Personality potential: Structure and evaluation]. (pp. 107-131). Moscow: Smysl.

Leontiev, D. A. (2001). Lichnostnaja zrelost' kak oposredovanie lichnostnogo rosta [Personality maturity as a mediator of personal growth]. In I.A. Petukhova (Ed.), Kul'turno-istoricheskaja psikhologija razvitija [Cultural-historical psychology of development]. (pp. 154-161). Moscow: Smysl.

Levinson, D. (1986). A conception of adult development. American psychologist, 41, 3-13. doi: 10.1037/0003-066X.41.1.3.

Lukina, E. A. (2006). Osobennosti samoosushhestvlenija cheloveka v raznye periody vzroslosti [Characteristics of self-fulfillment in different periods of adulthood]. (Unpublished doctoral dissertation). Saint Petersburg.

Manukyan, V. R. (2009). Cennostnye determinanty perezhivanija krizisov srednejj vzroslosti [Value determinants of crises experiences in middle adulthood]. In Materialy Vserossijjskojj nauchnojj konferencii "Psikhologija cheloveka v sovremennom mire" [Proceedings of the Russian scientific conference "Human psychology in the modern world"]. Vol. 3. (pp. 8390). Moscow: Institute of Psychology of RAS.

Morgun, V. F., \& Tkacheva, N. Ju. (1981). Problema periodizacii razvitija lichnosti v psikhologii [Problem of personality development pperiodization in psychology]. Moscow: Moscow University Press.

Muzdybaev, K. (1980). Smysl zhizni kak potrebnost' lichnosti [Life meaning as a personality need]. In A.A. Bodalev (Ed.), Lichnost $v$ sisteme kollektivnykh otnosheniy [Personality in 
the system of collective relationships]. (pp. 164-165). Moscow: Academy of Pedagogical Science Press.

Nartova-Bochaver, S. K. (2007). Psikhologicheskaja suverennost' kak kriterijj lichnojj zrelosti [Psycholgical souverenity as a criterion of personality maturity]. In A.L. Zhuravlev \& E.A. Sergienko (Eds.), Fenomen i kategorija zrelosti v psikhologii [Phenomenon and category of maturity in psychology]. (pp. 149-173). Moscow: Institute of Psychology of RAS.

Portnova, A. G. (2008). Lichnostnaja zrelost': podkhody k opredeleniju [Personality aturity: approaches to definition]. Sibirskijj psikhologicheskijj zhurnal [Siberian Psychological Journal], $27,37-41$.

Sergienko, E. A. (2007). Zrelost': moljarnyjj ili moduljarnyjj podkhod [Maturity: molar or module approach]? In A.L. Zhuravlev \& E.A. Sergienko (Eds.), Fenomen i kategorija zrelosti v psikhologii [Phenomenon and category of maturity in psychology]. (pp. 13-28). Moscow: Institute of Psychology of RAS.

Sheehy, G. (1999). Vozrastnye krizisy - stupeni lichnostnogo rosta [Age crises - steps of personal growth]. Saint Petersburg: Juventa.

Shljapnikova, I. A. (2010). Vzaimosvjaz' ehgo-identichnosti i lichnostnojj zrelosti [Ration of ego-identity and personality maturity]. (Unpublished doctoral dissertation). Russia, Cheljabinsk.

Slobodchikov, V. I., \& Isaev, E. I. (2000). Psikhologija razvitija cheloveka: razvitie sub"ektivnojj real'nosti $v$ ontogeneze [Develpental psychology of a human: ubjective reality development accross lifespan]. Moscow: Shkolnaja pressa.

Soldatova, E. L. (2007). Normativnye krizisy razvitija lichnosti vzroslogo cheloveka [Normative crises of adult personality development]. (Unpublished doctoral dissertation). Ekaterinburg.

Sukhobskaja, G. S. (2002). Ponjatie "zrelost social'no-psikhologicheskogo razvitija cheloveka” v kontekste andragogiki [Notion of social-psychological maturity of a person]. Novye znanija [New knowledge], 4, 17-20.

Tanner, J. L., \& Arnett, J. J. (2009). The emergence of "emerging adulthood": The new life stage between adolescence and young adulthood. In A. Furlong (Ed.), Handbook of youth and young adulthood: New perspectives and agendas (pp. 39-45). London: Routledge.

Vasilenko V. E., Manukyan V. R. (2006) Vozrastnye krizisy zhiznennogo cikla [Age crises of a life circle]. Saint Petersburg: Saint Petersburg University Press.

Original manuscript received February 28, 2014

Revised manuscript accepted March 29, 2015

First published online June 30, 2015 